October 2, 1933, another part of Ecuador, namely, the Santa Elena Peninsula, was strongly shaken by an earthquake. Weak local shocks often occur in the area.

\section{Michael Scot: Pioneer of Science}

Prof. J. READ has contributed an interesting study of "Michael Scot: a Scottish Pioneer of Science" to Scientia (Oct.-Nov. 1938). Michael Scot lived in the early part of the thirteenth century and worked as a translator of Arabic writings in Spain and Sicily, where he was court astrologer and philosopher to the Emperor Frederick II. In later times he acquired the reputation of a magician and necromancer, and many legends have gathered around his name. Although our knowledge of him is fragmentary, Prof. Read shows that Michael Scot was a man of genuine scientific interests. His views on alchemy are interesting, since it is significant that he mentions neither transmutation nor the philosopher's stone, so that he followed the Greek-Egyptian sources rather than the later authors of western Europe. Of his other works, Scot's "Physionomia" had an extensive circulation in manuscript for 250 years and afterwards in several printed editions. He also wrote on astronomy, astrology and the art of prediction, and stands out as the most eminent Briton to secure a place in the history of medieval Italy.

\section{The Imperial Institute}

THE annual report of the Imporial Institute (South Kensington, London, S.W.7) for 1938 shows that an important side of the work of the Institute lies in the research departments which answer an increasing number of inquiries from all parts of the Empire. Queries concern both seeds and roots of economic value and various mineral samples. The Mineral Resources Department was particularly active and reported on samples from various colonies. Special interest attaches to the demand for high grade quartz crystals for both piezo-electric and optical purposes, but so far the search for new sources of this material has had little success. The oxide of titanium known as rutile which is used in the coating of electric welding rods has been found invarious parts of the Empire. Many other examples of the usefulness of the Institute are recorded in this report.

\section{A Virus Disease of the Elm}

AMERICAN elm trees in the Ohio valley are subject to a new and deadly virus disease which is briefly described in a mail report from Science Service, Washington (Feb. 4, 1939). Leaves upon infected trees first shrivel and become brittle, then the roots and inner bark of the trunk rot away, and the tree dies within a few months. This is the first known instance where a virus disease has caused a fatal epidemic among trees. The outbreak appears to be even more serious than that of the so-called Dutch elm disease which has decimated elm trees in the neighbourhood of New York. It is reported that more than 1,000 out of about 1,800 elms in one particular locality have been killed by the virus during three years. Means of dissemination of the pathogene have not yet been found, but the United States Division of Forest Pathology is taking energetic measures to trace the extent of the infection, and to limit it to one district, if possible.

\section{Use of Electricity in Coal Mines}

ON the recommendation of the Royal Commission on Safety in Coal Mines, the Secretary for Mines has appointed a Committee with the following terms of reference: "To be a committee to consider, in the light of experience and modern practice, what amendments are required in the General Regulations governing the use of electricity below ground and above ground at mines under the Coal Mines Act, 1911, taking into consideration the report of the Royal Commission on Safety in Coal Mines and the evidence on the subject submitted to that Commission". The following are members of the Committee : Prof. W. Cramp, Department of Electrical Engineering, University of Birmingham (chairman); Mr. J. A. B. Horsloy, H.M. Electrical Inspector of Mines ; Mr. A. M. Bell and Mr. A. B. Connell. The secretary to the Committee is $\mathrm{Mr}$. R. Crawford, Mines Department, Mill House, 87-89 Shaftesbury Avenue, London, W.1.

\section{Chemical Society Anniversary Meetings}

THE anniversary meetings of the Chemical Society this year are to take place in London on March 29-31. On March 29 the Rutherford Memorial Locture will be delivered by Sir Henry T. Tizard at the Royal Institution at 5 p.m., and fellows and guests will be entertained at a reception and dance at Imperial Chemical House from 8.45 until midnight. On Thursday, March 30, visits have been arranged in the morning to Bedford College for Women and to the Wellcome Research Institution, to view the laboratories and museums. The annual general meeting will be held at Burlington House at 2.30 p.m., and at 4 p.m. the presentation of the Longstaff Medal and of the Harrison Memorial Prize will be made and Prof. F. G. Donnan will give his presidential address. The anniversary dinner of the Society will be held at Grosvenor House the same evening at 7 for 7.30 p.m. On Friday, March 31, visits have been arranged in the morning to The British Drug Houses, Ltd., and to the Central Laboratorios of the Shell Marketing Co., Ltd., and in the afternoon to the Research and Development Department of the Distillers' Company, Ltd. at Epsom, and to the laboratories of the Research Association of British Paint, Colour, and Varnish Manufacturers.

\section{Royal Society of Edinburgh: Elections}

Ar the ordinary meeting of the Royal Society of Edinburgh, held on March 6, the following ordinary fellows were elected: Prof. Arthur B. P. Amies, Australian College of Dentistry, Melbourne; Dr. William G. Annan, Clinical Medical Officer, Durharn County Council, Darlington; Prof. J. H. Baxter, Department of Ecclesiastical History, University of Continued on $p .431$. 
St. Andrews ; Dr. C. A. Beevers, Chemistry Department, University of Edinburgh; Dr. Amulyaratan Chakravarti, B. I. Research Laboratories, Calcutta; Mr. James Davidson, treasurer, Carnegie Trust for the Universities of Scotland, Edinburgh; Prof. Francis Davies, Department of Anatomy, University of Sheffield; Victor A. Eyles, senior geologist, H.M. Geological Survey (Scotland), Edinburgh; Ian Fraser, consultant surgeon, Belfast; Mr. J. G. Galloway, master of the Edinburgh Merchant Company, Edinburgh; Prof. Birendra Nath Ghosh, Department of Pharmacology, Carmichael Medical College, Calcutta; Prof. W. M. H. Greaves, Astronomer Royal for Scotland, Edinburgh; W. R. Hall, manager, Union Bank of Scotland (Head Office), Edinburgh; Dr. W. F. Harper, reader in anatomy, University of London, Department of Anatomy, London Hospital Medical College; N. M. Johnson, headmaster, Commercial Public School, Dunfermline; Dr. S. E. A. Landale, director of William Younger and Co., and of Scottish Brewers, Ltd., Edinburgh; Mr. C. E. Lucas, officer-in-charge, University College, Hull, Oceanographical Laboratory, Leith; Dr. J. W. Macfarlane, designer of electrical machinery and superintendent, Research and Specialpurpose Design, Glasgow ; J. I. G. MacGregor, assistant engineer (Scottish area), London and North Eastern Railway Co., Edinburgh; Dr. J. M. Mackintosh, chief medical officer, Department of Health for Scotland, Edinburgh; Prof. J. W. McNee, Department of Practice of Medicine, University of Glasgow; William Mair, manufacturing chemist (retired), Edinburgh ; Prof. D. C. Matheson, Department of Pathology, Bacteriology and Meat Inspection, Royal (Dick) Veterinary College, Edinburgh ; Lieut.Col. J. B. de W. Molony, I.M.S. (retired), Edinburgh ; A. C. Murray, manager and actuary, Scottish Equitable Life Assurance Society, Edinburgh; W. D. Oliphant, technical officer, Air Ministry, Bawdsey Manor Research Station, Woodbridge, Suffolk; Sir Arthur Olver, principal, Royal (Dick) Veterinary College, Edinburgh; W. A. Sinclair, lecturer in philosophy, University of Edinburgh; Dr. Bernard Halley Stewart, president, Halley Stewart Trust, London; Prof. G. M. Wishart, Department of Physiological Chemistry, University of Glasgow ; Sir Harold Edgar Yarrow, chairman of Yarrow and Co., Ltd., shipbuilders, etc., Glasgow.

\section{Announcements}

Prof. F. G. DONNAN, emeritus professor of chemistry in the University of London, has been elected an honorary member of the Société Philomathique of Paris. This Society was founded in 1788.

THe following have been elected honorary members of the Royal Meteorological Society : Jules Jaumotte, director of the Royal Meteorological Institute of Belgium, Uccle, near Brussels; Prof. Carl-Gustaf Rossby, professor-in-charge of the Meteorological Department, Massachusetts Institute of Technology ; Philippe Wehrlé, director of the National Meteorological Office of France.
The Hillebrand Prize for 1938 of the Chemical Society of Washington has been awarded to Raleigh Gilchrist and Edward Wichers, of the U.S. National Bureau of Standards, for their paper entitled "A New System of Analytical Chemistry for the Platinum Metals," presented before the Ninth International Congress of Pure and Applied Chemistry at Madrid.

Prof. Egon Ritter von Schweidler, hitherto general secretary, has been made vice-president of the Vienna Academy of Sciences, and Prof. Ernst Spath has succeeded him as general secretary.

A CHAIR of aerology has recently been instituted in the University of Rome and to it will be attached a laboratory for studies and researches in aerology. The first occupant of the chair is Prof. Filippo Eredia, whose address is Istituto di Aerologia, Via Emilo de' Cavalieri, 7 Rome, 106.

Dr. Bernard H. KNIGHT, lecturer in roadmaking in the College of Estate Management, London, has been recently appointed senior research assistant in highway engineering in the University of the Witwatersrand, Johannesburg.

COMPENSATION has recently been made for the use of the University of Bristol botanic garden for building purposes by the provision of another site on the Royal Fort estate. The new garden will be known as the Hiatt Baker Botanic Garden.

The centenary meeting of the Royal Microscopical Society will be held on October 25-26. Further information will be available later from the Secretary, Royal Microscopical Society.

THE next meeting of the International Society of Cosmobiology will be held during April 9-11 at Mentone. Further information can be obtained from the general secretary, Dr. Maurice Faure, 24 rue Verdi, Nice.

Tre Netherlands Congress of Natural Sciences and Medicine will be held at Nymwegen on April 11-13 under the presidency of Prof. G. Holst. Further information can be obtained from the general secretary, Dr. D. Collingh, Regentesselaan, 2, Bussum.

THE eighteenth International Congress of Agriculture will be held in Dresden during June 6-12, when the following subjects, among others, will be discussed : agronomy, crop production, disease, etc. ; vines, fruits and special crops; agricultural industries; agricultural research. Further information can be obtained from the general secretary, Dr. F. Sohn, Hafenplatz 4, Berlin, S.W.11.

A PRIZE of $\mathfrak{£ 2 0}$ and a diploma are awarded annually by the Royal Asiatic Society for an essay, the object being to encourage interest in the history and civilizations of the East among non-Asiatics. It is confined to members of certain universities. Further information concerning subjects for 1939 can be obtained from the Secretary, Royal Asiatic Society, 74 Grosvenor Street, London, W.I. 